\title{
SOME OBSERVATIONS ON CSR AND STRATEGIC MANAGEMENT
}

The notion of CSR and the notion of strategic management of companies are often thought to be contradictory. The former is associated with the aim of generation of profits while the latter idea is often associated with ensuring business earns a 'social license to operate'. However, emerging literature and practice suggests that a process of integration of the theoretical concepts and practices of CSR with strategic management is occurring. This paper describes some of the evidence for this so-called 'theoretical synthesis of economics and ethics' (Windsor). The first part of the paper starts with a description of commonly-used definitions of CSR and highlights critical differences. It continues by describing how aspects of CSR and strategic management are in some ways becoming more integrated at the organisational, strategy-setting and business management level at some companies. The paper then describes how theoretical approaches to CSR have the potential to become absorbed (and to enleaven) pre-existing strategic management theory. It concludes by giving a warning of potential hazards of incomplete integration of the two theories and practices.

Keywords: corporate social responsibility (CSR), business ethics, strategic management

Indicators show that, mainly due to the environmental foot print of a rapidly growing number of humans, the Earth's ability to act as a source of resources and a sink (reservoir) of pollution is rapidly declining. The earth's capacity to support a diversity and richness of human and non-human life at current levels is diminishing at an unprecedented speed ${ }^{1}$. This will create environmental changes and have social impacts on a scale and at a speed that has probably never been witnessed by humankind. The current fascination with CSR is in part a response to such a crisis.

\section{SELECTED ENVIRONMENTAL AND SOCIAL TRENDS}

- $20 \%$ of all land mammals are under threat of extinction,

- 75 per cent of the world's fisheries are already either "fully exploited", "over exploited" or significantly depleted,

- 13 million hectares of the world's forests are lost due to deforestation each year,

- an estimated $42 \%$ of people in rural Africa have no access to clean drinking water,

- approximately $41 \%$ of Africa's population live on less than $1 \$$ per day.

\section{What is Corporate (Social) Responsibility?}

CSR has been used as a synonym for business ethics and also for corporate philanthropy. CSR has also been used to describe CSP (corporate social performance) and corporate citizenship (which usually emphasises the contribution a company makes to society through core business activities, social investment and/or engagement in good causes) and good corporate governance (which usually reflects the way companies address legal responsibilities). CSR and corporate sustainability are overlapping movements, though not identical.

Defining CSR is therefore subjective, in part due to the central concept of Responsibility, a notion which may rest on one's personal perspective. One problem is that definitions of CSR (just as with business norms and standards and regulatory frameworks) vary across and between nations, regions, businesses and stakeholders. Some selected definitions of CSR from the literature are:

- 'a theoretical synthesis of economics and ethics'(Windsor, 93-114),

- 'regardless of specific labelling, any concept concerning how managers should handle public policy and social issues', 
- 'actions on the part of the firm that appear to advance, or acquiesce in the promotion of some social good, beyond the immediate interests of the firm and its shareholders and beyond that which is required by law'(McWilliams - Siegel, 2001),
- CSR is a 'market for virtue' (Vogel).

A classic description of CSR comes from Carrol (1979) who developed four categories of Corporate Social Responsibility activities: Economic responsibilities ("the first and foremost...social responsibility of business \{is\} in the production and sale of goods and services and the generation of profits" Legal responsibilities: (compliance with regulation) ethical re-
sponsibilities (a set of societal norms wider than the sponsibilities (a set of societal noms wider than the legal minimum) and also discretionary or philanthropic responsibilities (voluntary activities such as social p.ogrammes and/or charitable donations) (Figure 1 .

\section{Two 'kinds of CSR'?}

While the formal definition of sustainability should be interpreted in the broader context of environment, economy and society, as framed in the scientificallyinformed Brundtland Report, there is a clear risk and some evidence that reframing (narrowing) of the concept of 'sustainability' within business is occurring. For example, the word sustainability is more and more often found paired with profit, as in 'sustainable profit'. To some, the word 'sustinabe' is closely associated with 'competive 'sulated 'sustaiblit ' 'sustainability' has cone to be unilised as an important "the sur of sound strategy-making (e.g. in references to "the sustainable, long-term success of the company"). It is useful to consider the following distinctions between the broader definition of CSR, and the more directly business-related definition:

Figure 1

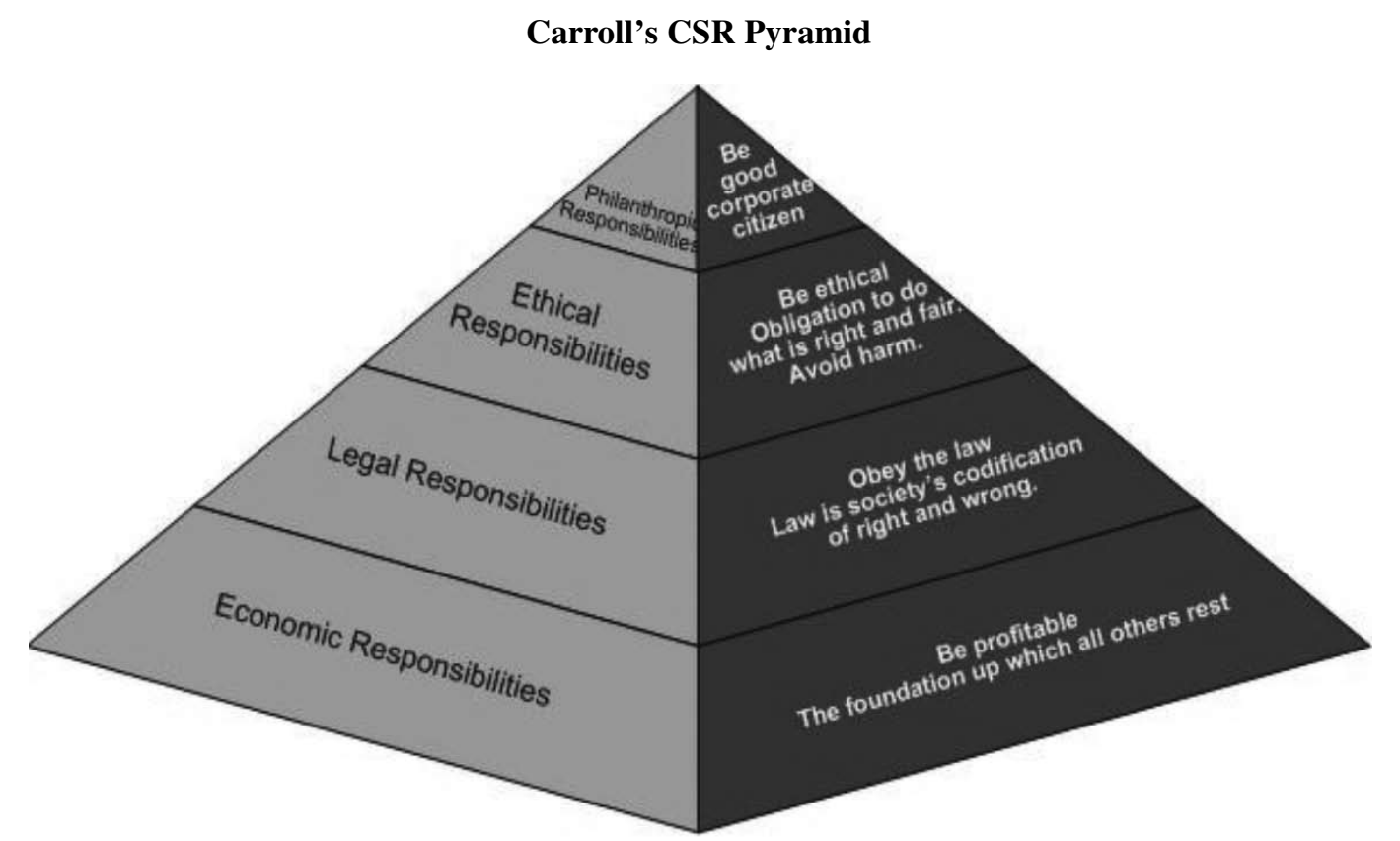

Other definitions include ideas of businesses incorporating the 'Triple-P bottom line' (Profit - through porating the "Triple-P botom line' (Profit - through sales, production, enployment and sources of income), People (intra and extra-company social dimension) an Planet (responsible management of environmental resources), and the well-known WBCSD ${ }^{2}$ definition of creating sustained economic value while contributing to the quality of life of shareholders. Notions of 'going beyond regulatory compliance' and wider stakeholder involvement are common to many definitions of CSR Framing of the concept of CSR is critical. It may be useful to consider the following two definitions, the first of which takes a wider frame of reference.
Definition 1: CSR as a subset of the sustainability movement aimed at addressing challenges of longerterm environmental stewardship, conservation and equity (related to the kind of data provided in box 1 above), as part of a new world order based on a global partnership for sustainable development;

Definition 2: CSR as a primarily business management approach that is aimed at maximising long-term shareholder value, and additionally providing value for other stakeholders.

It can be seen that there are significant differences between the two terms, although they are not theoretically irreconcilable. Noticeable is a reframing and nar- rowing of the definition to exclude explicit mentio of 2 pillars of sustainability (environment, society) Definition 2 and a focus of the term around the word 'value'; another subjective word. Should this be a cause for concern?

\section{CSR as a strategic - business management -} approach

Vogel (2005) presents examples in a recent book to indicate there is a clear business case for CSR. He writes that the emergence of 'companies with a conscience' is due to a reconilition of conscience" is due to a reconciliation of social values and business systems. He adds that CSR is not "a precondition for business success but a dimension of corporate strat egy". Regardless of company motives for integrating CSR into strategy-making processes, there is a stron argument that CSR should be considered a strategcally important concept for organisations (at the level of the business and in individual organisations). Thes arguments for the strategic integration of CSR into business models go beyond simple attempts to link financial performance to proxy measures of CSR using various indicators (e.g. Kanter, 1999). Many such studies, in any case, have been inconclusive - fin ing negative, positive and curvilinear relationships ing Siegel, 2001 - for a though - Siegel, 2001

Further complicating the issue is when the notions of 'beyond compliance' come into play - how do companies deal with CSR if it is suggested that, the interests of sustainability, they should spend capita to achieve other non - or indirectly - profit-oriented goals? If CSR activities are indeed being employed at companies, it would be useful to understand to what extent they are indeed driven by strategic motives, and what those strategic motives are. Further, are such CSR efforts more in line with definition 1 or definition 2 of CSR?

A recent survey of 111 Dutch companies attempted to measure managers' attitudes toward and motivatio for implementing CSR activities by asking for level of agreement with the following statements:

'Our firms' own effort with respect to CSR will have a positive influence on our financial view of $(S R)$, and

To behave in a responsible way is a moral duty of businesses towards society' (to capture the moral view of CSR.
Results from this survey were cross-checked against tual company efforts to implement CSR practices. Results showed that a majority of respondents had a positive view of CSR in both dimensions. Interestingly, only a weak correlation was found between the strategic view and actual CSR efforts (the strategic view generated active CSR policies only with respect to consumer relations and employee relations). In relations with suppliers, competitors and society, and the use of instruments to integrate CSR in the organisation, a positive strategic view made only a very small difference with sect to actual CSR efforts. However, a positive with view of CSR was me "str. However, a posive moral ve" " with employees, customers and the use of instruments

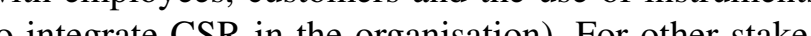
holders the CSR in the organisation). For other staketo formance. The authors conclude:

"The result that CSR implementation is more related to moral commitments than profit maximisation implies that one should be careful when emphasising the financial advantages of CSR" (Graafland - Bert van de ven, 2006).

This finding is echoed in work by Sratling (Sratling, Tho who empirically (company survey) based paper concludes:

"A surprisingly limited number of the companies in the sample take a very explicit strategic approach to CSR by stressing long-term shareholder value maximisation. The CSR policies therefore appear not to focus solely on a strateic stakeholder approach geared towards maximising shareholder value".

A 2005 KPMG Survey of corporate responsibility report also highlighted diverse motivation for corporate responsibility (a weighting of 74\% economic and $53 \%$ ethical was discovered - although it should be remered that 'stated preference' type techniques remembered that 'stated preference' type techniques re CSR-y, activits, o nonCSR-type activities, to non- or only indirectly strategic company goals, this has implications which are worth investigating further (under which circumstances are company agents behaving in contradiction to the theory of the firm and why is this so?). These findings appear to highlight some tension inherent in the understanding and actualisation of the 2 definitions of CSR provided earlier. Theories such as 'legitimacy theory' may assist in understanding further - more on which below. 


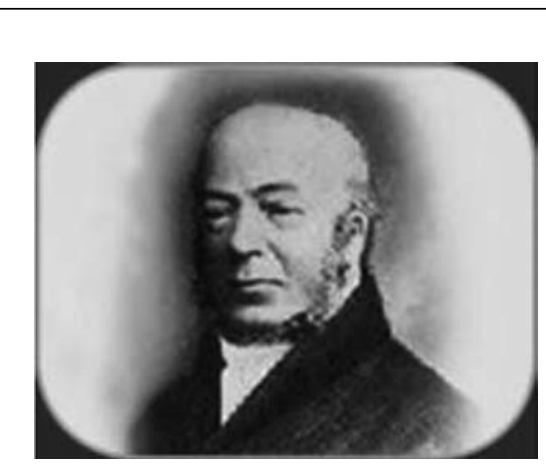

John Cadbury

(1801-1889)

Historical examples of corporate social responsibility as a strategic objective can be found in the business practices of employee and stakeholder-centric

companies such as the original their current CSR practices dif'Cadbury' company which was fer substantially from the former ounded in the UK in Victorian practices. Other historical examtimes. In 1879, Bournville vil- ples of what might now be called lage was founded for the benefit CSR as business strategy inof Cadbury's workforce. The vil- clude actions by Kodak founder lage included housing for workers George Eastman (who gave over who benefitted from works com- one-third of his own company to mittees, medical facilities, sports his employees and established facilities, pension funds and edu- for them a retireme fund, life for them a retirenent fund, life cation and training-well beyond insure ald disability/health cons. The company was lead by loges and Carnegie ant Kellaws. The company was lead by loggs and Carrnegie and those the founder, John Cadbury, who others whose focus was as much was significantly motivated by a on what is now termed the 'interbelief in Quaker (essentially hu- nal stakeholders' (employees) as manist) ethics. While Cadbury's on profit-making; these figures is now one of the most success- are sometimes known as the 'beful confectioners in the world nevolent paternalists'.

\section{CSR as Strategy}

CSR is potentially a strategic matter in so far as it has the potential to change the entire frame of reference (organisational purpose or mission) of the company. This is true whether CSR definition 1 or definition 2 is concerned Multinational companies now typically integrate (or wish to appear to be integrating) some integrate (Or wh to their definition of vating) some aspects (OF CSR into aperr to be inge-creation ( at a strategic level.

A recent Accountability study across 8 countries of central-eastern Europe concluded that $63.2 \%$ of 288 large companies surveyed are either 'on the way' or display 'good practice' in CSR engagement in the realm of strategy (UNDP, 2007). Concomitant with this survey is a clear sign of demand for the strategic management of CSR activities and assets (Porter - Kramer, 2002).

Accountability (UNDP) defines 6 areas in which CSR engagement may be displayed by companies: Strategy, Stakeholder Engagement, Governance, Performance Management, Public Disclosure and AsurStre ace. It is not clear how Pexclic Disclose categories are. According to Katsoulakos (2006) CRS
agement involves four main activities:

1. CRS policies, strategies and performance/ risk indicators need to be developed as an integral part of the overall corporate strategy to reflect the re-
2. Strategies should clarify corporate responsibility positioning decisions in light of benchmarking position then be periodically validated.

3. Governance structures, transparency standards and controls should be reviewed and adjusted as necessary to support the agreed CRS policies and strategies which may take a number of iterations to reach proper alignment.

4. A CSR capability development programme should be specified to support the implementation of the strategies in the context of the specition of the strategies in
fied governance design.

Following on from point 1 , another strategic approach to involving CSR in strategy can be to treat stakeholders such as NGO's as strategic service providers (effectively making them strategic partners) in the delivery of the company's corporate social respon作 列 cyond company could recoup costs based on the full activity based cost of integrated corporate social responsibility accounting. Increasing performance (point 2) may also be a strategic objective and compound indicators for CSR (such as the newly minted ISO2600CSR management standard ${ }^{4}$ ) may also play a role. Potential strategic goals may include the ulilization of codes of conduct, charters, the use of ISO 14001 or other health and safety and socially responsible investment indices
- for example, voluntary compliance with the $100+$ components of the ISO26000 standard - which cover all aspects of company operation from environment to investment and resources management. Other ways in which CSR may be integrated into business management as a performance objective during wider strategy setting include the use of the balanced scorecard approach ("tying values and measures to a Balanced Scorecard could be the way to make good intention more profitable" (Crawford - Scaletta, 2005). Furthe ways in which CSR may be integrated into strategic mans is is ment procedures, $n$ tion and 'green' marketing) and eco-efficiency.

\section{CSR and Strategic Management - potentia} theoretical consilience

A question for strategic management theory is seeing a theory of CSR decision-making can be founded th does not contradict the basic principles of the classical theory of the firm (essentially, can CSR practices fit within the profit-making nature of the firm?) Should CSR be considered as a form of strategic investment? If CSR is not directly tied to a product or production process, can CSR in the form of reputation building or process, car CSR in the for pr, whe ly, whe imp Is ther a risk has issue have? Is there a risk that by trying to shoehor CSR into a narrower business-management definitio (in keeping with the theory of the firm) we lose the original value of CSR as part of a broader sustainability initiative? To identify how CSR is being considered as a strategic issue, a key question is: To what extent are CSR decisions considered similar to other decisions that companies take? A growing literature seeks to address these questions (e.g. Porter - Kramer, 2002).

Milton Friedman was one of the first people to publicly voice concern over CSR and suggested that the existence of CSR was a sign of an intra-company agency problem (agency theory could imply that CSR is a mispre of (agency theory conld imly use of corpont rent

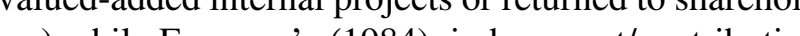
ers) while Freenan's (1984), inducement/contribution framework, presented a more positive view of CSR the company. Research by Husted, Allen and Rive (2008) attempts to provide a CSR framework based o corporate governance. Governance concerns how companies deal with legal responsibilities and can stand as a foundation on which CSR and corporate sustainability practices may be built. The authors note that a firm may either "buy" CSR (primarily outsourcing to NGO"s or philanthropy) or "make" CSR internally (in-house projects), or collaborate with other organizations in the developinent of CSR projects. Managenent objectives are to determine which response benefits the firm in form of return on investment and stakeholder satisfaction. If the two objectives cannot be reconciled, the firm is unable to meet obligations. The extent to which CSR will be used to pursue strategic opportunities, in their opinion, is a management - and governance - decision. Legitimacy theory (i.e. appeals founded on a 'justification' basis) are substituted for strategic concerns if such concerns are not strong nough. If the firm accords CSR a strag ally a clo roleth of fit becon the fin's CSR - usually a closeness of Cit between the firm's CSR activity and its mission and objectives occurs when the firm's CSR activity is closely related to core business activity). When this so-called 'centrality' is high, the principal-agent problem is weak (the company can monitor social activities related to its core competencies). But when centrality is low, agency costs increase and the tendency to outsource CSR is higher. Legitimacy theory (from Stratling, 2007), defines four main strategies that firms can employ to generate legitimacy:

1) the firm can inform its public about changes in its performance and activities

2) the firm can try to change the public's perception of the firm's behaviour without actually changing the behaviour,

3) the firm can try to deflect attention away from contentious issues by raising the profile of related activities; (a common approach),

4) the firm can try to change public's expectations about its performance.

If core competences and dynamic capabilities (from resource based theory- addressing how companies can perform activities within the value chain more efficienty by utilizing firm-specific resources which are valuable, rare, imperfectly imitable and non-substitutable) involve firm-specific assets or resources that allow it to ted to its fundamental business, CSR activity is more likely to be highly central (the firm possesses the competences needed to unertake that activity) and the activity is less likely to be outsourced. When centrality is low, information asymmetry may be high so a third party (or philanthropic onation) is more likely to be deemed suitable to fill the perceived CSR needs of the company.

If we define resources widely as being "anything tangible or intangible that would be both useful and available to an organisation in carrying out its valuecreating activities-including products, processes, pat- 
ents, reputation, customer relations, human capital, etc." (Katsoulakos, 2006), then it is clear how aspect of CSR may be considered resources (for example, environmental social responsibility may constitute such resource or capability that can lead to sustained competitive advantage). Other responsibility related competencies and capabilities may include such things as accurate estimation of the social and environmental impact of company operations and potential for their development. While many companies may focus currently on the PR aspects of CSR (i.e advertising) and (possbly) developing environmentally-friendly products gin a 'responsts, gain a 'responsibility advantage "will mean developing the responibility resource (developing superior responsibility performance to competitors) to maintain their competitive lead in this area. With responsibility widely perceived as a key resource (presumably as component of brand value) mainstreaming of the CSR concept (strategically-speaking) would be likely.

Alternative approaches to addressing the question of CSR and strategic management integration focus on industrial organization/environmental theory. Strategies for developing core competencies may be combined with networking and knowledge management strategies, and be predicated on the learning capability of the firm (learning curve). Stakeholder (instrubilty of the egy mean hile, may book to support or enlat egy meanwhile, may tage-creating (usully tust-based) resources such as employee motivation, custoriter loyalty, ability to influence regulation, or social license to operate. When CSR and strategic management are integrated, strategic and tactical decisions are automatically evaluated for impact on the firm's stakeholders. If stakeholders are neglected (the theory goes) they may withdraw support for the operation. In practice, boycotts of companies and divesting of financial capital is quite rare. Stakeholder theory which emphases a wide set of social responsibilities for business reflecting the diversity and contractual nature of stakeholders involved in the firm - was established by Freeman in 1984 (in his book "Strategic management: A stakeholder approach). Stakeholder theory was furA stakerended to include the moral and exthe was further expand the dimensions of CSR by Dona ardship theory meanwhile, (Donaldson - Davis, 1991) is based on the theory that there must be moral drive for managers to 'do the right thing', even when this a fects financial performance (examples of such behaviour are provided in the former chapter). Institution theory and classical economic theory may also be applied to CSR. Companies involved in transactions with stakeholders on the basis of trust and cooperation are more likely to be motivated to be ethical and hone

because this is more likely to lead to repeat business. Institutional theory (concerning the role of institutions in shaping the consensus within a firm) may be used to examine how the environmentally-sustainable firm can emerge. Strategic leadership theory, meanwhile, can be used to examine how (strategically-inclined) positive leadership tendencies can correlate with CSR efforts. A cost-benefit approach to CSR may also be tested. A thought experiment by McWilliams and Siegel (2001) was undertaken in which two companies produce identical products - except that one firm adds an additional 'social' attribute or feature to one product and keeps track of seles da In this way, it is theoct and keeps sible to soles data. In this way, it is theoretically poslevel of rescures to devote to CSR activites. CSR the level of resources to devote to CSR activities. CSR may also be used in the context of political strategies aimed at gaining advantage through regulatory barriers to imitation. This is partly captured in the quote that "CSR is a barrier to trade" ${ }^{5}$ (Table 1).

One subset of business networks deals with strategic alliances and refers to formal long-term, formal collaboration between organisations that offers actual or potential strategic advantages to the partners involved. The tendency for firms to engage in such (albeit usually temporary) alliances with non-governmental organisations (e. . McDonalds and the American Environmental Defence Fund or the World Willife Fund occurig fore are gitining for rasons of knowledge exchange and legitimacy. If business networks can be said to represent company social capital, a networking approach has the potential to assist in the establishment of competence and governance-focused network relation

The knowledge view of the organisation focuses on knowledge resources as the key source of competitive advantage. Such knowledge at the firm level may be seen in the form of corporate responsibility training (sometimes as a part of a knowledge management strategy) but often as a distinct activity aimed at developing core competencies and benefiting the internal (and sometimes external - wider community) stakeholders of the company through professional developenters

The corporte responsibility perspective, Thile, covers many areas while, covers many areas such as corporate governability and the 'triple bottom line' (although SSR ability and the 'triple bottom line' (although CSR may be more associated with ethical issues). Corporate Sustainability is a specific term usually associated with company involvement in and support for the principle of sustainable development (and inevitably the long term survival of the corporation). Typical drivers for CSR and corporate sustainability usually include (modified from Katsoulakos):

VEZETÉSTUDOMÁNY
Theoretical Perspectives that relate to

CSR, from McWilliams (2006)

\begin{tabular}{|c|c|c|}
\hline Author & $\begin{array}{c}\text { Nature of } \\
\text { theoretical } \\
\text { perspective(s) }\end{array}$ & Key argument/result \\
\hline $\begin{array}{l}\text { Friedman } \\
(1970)\end{array}$ & Agency theory & $\begin{array}{l}\text { CSR is indicative of self-serving behaviour on the part of managers, } \\
\text { and thus, reduces shareholder wealth }\end{array}$ \\
\hline $\begin{array}{l}\text { Freeman } \\
(1984)\end{array}$ & $\begin{array}{l}\text { Stakeholder } \\
\text { theory }\end{array}$ & $\begin{array}{l}\text { Managers should tailor their policies to satisfy numerous constituents, } \\
\text { not just shareholders. } \\
\text { These stakeholders include workers, customers, suppliers, and community } \\
\text { organizations }\end{array}$ \\
\hline $\begin{array}{l}\text { Donaldson } \\
\text { and Davis } \\
(1991)\end{array}$ & $\begin{array}{l}\text { Stewardship } \\
\text { theory }\end{array}$ & $\begin{array}{l}\text { There is a moral imperative for managers to 'do the right thing', without regard to } \\
\text { how such decisions affect firm performance }\end{array}$ \\
\hline $\begin{array}{l}\text { Donaldson } \\
\text { and Preston } \\
(1995)\end{array}$ & $\begin{array}{l}\text { Stakeholders } \\
\text { theory }\end{array}$ & $\begin{array}{l}\text { Stressed the moral and ethical dimension of stakeholder theory, as well as the } \\
\text { business case for engaging in CSR }\end{array}$ \\
\hline Jones (1995) & $\begin{array}{l}\text { Stakeholder } \\
\text { theory }\end{array}$ & $\begin{array}{l}\text { Firms involved in repeated transactions with stakeholders on the basis of trust and } \\
\text { cooperation have an incentive to be honest and ethical, since such behaviour is } \\
\text { beneficial to the firm }\end{array}$ \\
\hline Hart (1995) & $\begin{array}{l}\text { Resource- } \\
\text { based view of } \\
\text { the firm }\end{array}$ & $\begin{array}{l}\text { For certain companies, environmental social responsibility can constitute a resource } \\
\text { or capability that leads to a sustained competitive advantage }\end{array}$ \\
\hline $\begin{array}{l}\text { Jennings } \\
\text { and } \\
\text { Zandbergen } \\
(1995)\end{array}$ & $\begin{array}{l}\text { Institutional } \\
\text { theory }\end{array}$ & $\begin{array}{l}\text { Institutions play an important role in shaping the consensus within a firm regarding } \\
\text { the establishment of an 'ecologically sustainable' organization }\end{array}$ \\
\hline Baron (2001) & $\begin{array}{l}\text { Theory of the } \\
\text { firm }\end{array}$ & $\begin{array}{l}\text { The use of CSR to attract socially responsible consumers is referred to as strategic } \\
\text { CSR, in the sense that firms provide a public good in conjunction with their } \\
\text { marketing/business strategy }\end{array}$ \\
\hline $\begin{array}{l}\text { Feddersen } \\
\text { and Gilligan } \\
\text { (2001) }\end{array}$ & $\begin{array}{l}\text { Theory of the } \\
\text { firm }\end{array}$ & $\begin{array}{l}\text { Activists and NGOs can play an important role in reducing information asymmetry } \\
\text { with respect to CSR on the part of consumers }\end{array}$ \\
\hline $\begin{array}{l}\text { McWilliams } \\
\text { and Siegel } \\
(2001)\end{array}$ & $\begin{array}{l}\text { Theory of the } \\
\text { firm }\end{array}$ & $\begin{array}{l}\text { Presents a supply/demand perspective on CSR, which implies that the firm's ideal } \\
\text { level of CSR can be dtermined by costbenefit analysis }\end{array}$ \\
\hline $\begin{array}{l}\text { McWilliams et } \\
\text { al. (2002) }\end{array}$ & $\begin{array}{l}\text { Resource- } \\
\text { based view of } \\
\text { the firm }\end{array}$ & $\begin{array}{l}\text { CSR strategies, when supported by political strategies, can be used to create } \\
\text { sustainable competitive advantage }\end{array}$ \\
\hline $\begin{array}{l}\text { Waldman et } \\
\text { al. (2004) }\end{array}$ & $\begin{array}{l}\text { Theory of the } \\
\text { firm/ strategic } \\
\text { leadership } \\
\text { theory }\end{array}$ & $\begin{array}{l}\text { Certain aspects of CEO leadership can affect the propensity of } \\
\text { firms to engage in CSR. } \\
\text { Companies run by intellectually stimulating CEOs do more strategic CSR than } \\
\text { comparable firms }\end{array}$ \\
\hline
\end{tabular}

\section{VEZETÉSTUDOMÁNY}


- self regulation (codes of conduct, improvement in occupational health and safety, environment protection and social and environmental reporing),

alignment with national sustainability strategies,

Socially Responsible Investment (SRI) and corporate sustainability indexes,

- risk management,

- satisfying consumer preference,

complying with goals and principles for responsible corporate behaviour (e g. Global Compact)

incorporation of stakeholder concerns,

- increasing eco-efficiency (decreasing costs),

- improvement in supply chain processes,

- improven ent in supply chain processes.

- developing human capital (by means of talent at traction and retention, motivation and participation of employees),

opening market opportunities (social innovation and green products and services) (Table 2).

urrent form and function to its socially-agreed role as a producer of wealth" (Sundaram - Inkpen, 2004).

Regardless of the success of the academic or practice integration of CSR into the field of strategy making (the partial success of which seems inevitable) fundamental concerns about corporate (and thus environmental and social) sustainability remain.

The problems centres on the clear and present danger that CSR, as framed from the business perspective (i.e. according to definition 2 provided earlier) is not in accord with the broader principles of sustainability given in definition 1 , and is thus not in accord ples of natural science (see, e.g. Korhounen, 2006). Even a cursory comparison between economic and natural systems shows that the principles on which modern industry operates - towards (basically) unlimited growth (rather than bounded growth), specialization (rather than diversification), mass production (rather than limited

Table 2

Strategic Theory and Value and CSR relationship

(modified from Katsoulakos)

\begin{tabular}{|l|l|l|}
\hline \multicolumn{1}{|c|}{ Theory } & \multicolumn{1}{|c|}{ Strategic aspect/value } & \multicolumn{1}{c|}{ CSR relation } \\
\hline $\begin{array}{l}\text { Industry Organisation } \\
\text { Environment based theories }\end{array}$ & $\begin{array}{l}\text { Market analysis } \\
\text { Strategic positioning and value propositions }\end{array}$ & $\begin{array}{l}\text { Industry level sustainability analysis } \\
\text { Fair globalisation }\end{array}$ \\
\hline Resource Based View & $\begin{array}{l}\text { Advantage-creating resources. } \\
\text { Core competencies }\end{array}$ & $\begin{array}{l}\text { Respon impact and improvement capabilities } \\
\text { Responsibility competencies mainstreaming }\end{array}$ \\
\hline Business Networking & $\begin{array}{l}\text { Relation-specific assets } \\
\text { Complementary assets } \\
\text { Transactional cost minimisation }\end{array}$ & Sustainable development support networks \\
\hline Learning perspective & $\begin{array}{l}\text { Advantage-creating knowledge (intelligence, } \\
\text { change management) } \\
\text { Learning curve }\end{array}$ & $\begin{array}{l}\text { Human capital/Professional development } \\
\text { Stakeholder training }\end{array}$ \\
\hline $\begin{array}{l}\text { Corporate Responsibility } \\
\text { and Sustainability }\end{array}$ & $\begin{array}{l}\text { Self) Regulation } \\
\text { SRI related strategies } \\
\text { Green products strategies } \\
\text { Responsibility positioning } \\
\text { Transparancy } \\
\text { Risk management } \\
\text { Brand and reputation }\end{array}$ & $\begin{array}{l}\text { Ethics } \\
\text { Accountability }\end{array}$ \\
\hline $\begin{array}{l}\text { Stakeholder oriented strategic } \\
\text { management }\end{array}$ & $\begin{array}{l}\text { Stakeholder instrumental value related strategies } \\
\text { Social capital }\end{array}$ & Stakeholder intrinsic approaches \\
\hline
\end{tabular}

\section{Limitations of the business management}

\section{approach to CSR}

"Critically, no theory of CSR decision-making will endure if it contradicts the most fundamental principle of the business firm - the creation of wealth - however beneficial the results of CSR for certain stakeholder groups. We cannot forget that the firm, as a legal entity, owes it self-sufficiency) globalisation (rather than localisation) speed (rather than harmony) contrast with fundamental ecological principles which have successfully maintained a wide diversity of life on earth for billions of years.

Despite some progress achieved in integrating CSR into strategy making in the fields of theory and practice, current corporate CSR practices gener- ally concern only a small number of (multinationa western-centred, well-financed) companies that have made corporate sustainability a defensive busine philosophy typically in response to criticism or crisis. Even these successes are limited; criticism of the role and value of CSR in Multinational companies is rifesee, for example, Frynas Additionally, formal CSR practices may be perceived as being of limited use (or worse) in the majority of businesses - the SME sector. Current times of financial hardship, or a drop off in customer demand for the CSR resource add to off in custor

According to the UNDG, "We will have time to reach the Millennium Development Goals - worldwide and in most, or even all, individual countries - but only if we break with business as usual" This type of change would involve fundamentally changing the role of the company, "reconstitute\{ing\} the firm, instituting new form of governance, in effect creating a new kind of organization" (Husted - Allen - Rivera).

What would such a company look like? According to Paul Hawken (1993), this means rethinking the fundamental purpose of business and economy in order to "creat \{e\} a very different kind of economy, one that can restore ecosystems and protect the environment while bringing forth innovation, prosperity, meaningful work and true security". This requires re-appropriating the true value of CSR as part of the sustainability movement and re-founding economies based on limits of the natural world, while ensuring price signals reflect 'value' in all it's broader meaning. This is no small task but working towards such reformation must becon the true strategic challenge for managers, theorists and practitioners of business.

\section{Footnote}

Data taken from:

http://www.unep.org/geo/yearbook/yb2007/PDF/_

Overview72dpi.pdf

http://www.un.org/millenniumgoals/docs/MDGafrica07.pdf World Business Council for Sustainable Development: http:// www.wbcsd.org

Default.aspx?TabID=1278\&KPMGArticleI

http://isotc.iso.org/livelink/livelink/fetch/2000/2122/830949/39 $34883 / 3935096$
Nelson Mandela

\section{References}

Carroll, A.B. (1979): A Three-dimensional conceptual model of corporate performance. Academy of Management Review. 4:4
Crawford, D. - Scaletta, T. (2005): The Balanced Scorecard and Corporate Social Responsibility: Aligning Values CMA Management

Donaldson, L. - Davis, J.H. (1991): Stewardship theory or agency theory: $\mathrm{CEO}$ governance and shareholder returns. Australian Journal of Management. 161 1: p. 49-64.

the modern cortorion: $L$. Cons tions. Academy of . Concepts, evidence and implicaions. Acad (1984): Strage approach. Pitman, Boston

Fynas, J.J.G. (2005): The false developmental promise of Corporate Social Responsibility: evidence from multinational oil companies._International Affairs. $81: 3$

Gert van de ven. (2006): Strategic and Moral Motivation for Corporate Social Responsibility Journal of Corporate Citizenship. 22

iffin, J. (1997): The Corporate Social Performance and Financial Performance Debate. Business and Society_36:1

usted, B.W. - Allen, D.B.- Rivera, J.E. (2008): Governance Choice for Strategic Corporate Social Responsibility Evice (1999): Glal Anerica. Business \& Society. Washington Quarterly, 22:2: p. 39-58.

Katsoulas, P. Katsoulakos, $Y$ (2006): The value, responsiveness and responsibility dimensions of strategic management. 4CR Working Papers (Parts A, B, C and D) Athens University of Economics and Business

Korhounen, J. (2006): Of corporate social responsibility: how can we use social science and natural science for a new

McWillian Bus A - Siegl, D. A European Review. 15.2.2 Williams, A. - Siegel, D.S. - Wright, P.M. (2006): Corporate Social Responsibility. Strategic Implicalons. Jour.

cWilliams, A. - Siegel, D. (2001). Corporate social responsibility: A theory of the firm perspective Academy of Management Review, 26:1: p. 117-127.

Pataki, G. (2009): Ecological modernization as a paradigm of corporate sustainability. Sustainable Development. 17:2 tage of Corporate Philanthropy : The Competitive Advantage of Corporate Philanthropy. Harvard Business Review Sratling, R. (2007): The legitimacy of Corporate Social Responsibility. Corporate Owhership and Control. 4:4 tive revisited. Organ. Sci. 15:3:350-363.

NDP (2007): Baseline study on CSR practices in the new EU member states and Candidate Countries

gel (2005): The Market for Virtue. The Brookings Institution, Harrisonburg, Virginia

indsor, D. (2006): Corporate Social Responsibility Three Key Approaches. Journal of Management Studies. 43.1 p. 93-114.

Article provided: 2009. 10.

\section{VEZETÉSTUDOMÁNY}

